\title{
Catalytic properties and polymorphism of serine endopeptidases from the midgut gland of the brown shrimp Crangon crangon (Decapoda, Caridea)
}

\author{
Reinhard Saborowski • Jessica Schatte • \\ Luis Gimenez
}

Received: 2 August 2011/Accepted: 19 January 2012/Published online: 30 March 2012

(C) Springer-Verlag 2012

\begin{abstract}
The brown shrimp Crangon crangon is a key species in the coastal areas of the North Sea. It constitutes a significant food source for fishes. Simultaneously, it is an important predator on a wide range of invertebrates. C. crangon shows a variety of digestive enzymes that allow to utilizing a wide range of food items. The initial step of alimentary protein digestion, that is the degradation into peptides, is facilitated by set of endopeptidases which are expressed by the midgut gland. In crustaceans, these endopeptidases are often dominated by serine proteinases. C. crangon, however, predominantly express cysteine proteinases, while only some specimens show a highly variable pattern of serine proteinases. The composition of these serine endopeptidases was investigated using liquid chromatography, substrate gel electrophoresis and inhibitor assays. Distinctly elevated activities were present only in about $10 \%$ of the samples. When activity was detected, two peaks, one with tryptic activity and the other one with chymotryptic activity, could be separated by anionic exchange chromatography. Moreover, specimens with elevated tryptic activities often showed highly polymorphic patterns of endopeptidases after electrophoretic separation. Overall, 30 different bands of endopeptidases were identified. There was no similarity between animals from the
\end{abstract}

Communicated by H. O. Pörtner.

R. Saborowski $(\square) \cdot$ J. Schatte $\cdot$ L. Gimenez

Alfred Wegener Institute for Polar and Marine Research,

Functional Ecology, PO Box 120161,

27515 Bremerhaven, Germany

e-mail: Reinhard.Saborowski@awi.de

L. Gimenez

School of Ocean Sciences, University of Wales,

Bangor, Menai Bridge, Anglesey LL59 5AB, UK same sampling sites, neither between animals of similar size, weight or nutritive state. The polymorphism of proteinase from the midgut gland seems to reflect the high adaptive potential of this species to variable trophic conditions in a continuously changing environment.

\section{Introduction}

The brown shrimp Crangon crangon is a dominating member of the epibenthic fauna of the North Sea and, particularly, the coastal and Wadden areas (del NorteCampos and Temming 1994). Its feeding mode is omnivorous and opportunistic (Gibson et al. 1995; Pihl and Rosenberg 1984; Wilcox and Jeffries 1974). Stomach content analysis showed that the composition of ingested organisms widely reflected the composition of potential prey organisms in the habitat (Pihl and Rosenberg 1984; Plagmann 1939). Immediately upon ingestion, the macerated food is hydrolysed by the digestive enzymes.

Crustaceans express a set of highly active digestive enzymes which hydrolyse the major food items. These enzymes include various proteinases, lipases, esterases and glucanases (Dall and Moriarty 1983). Particularly the proteinases appear in many species with high activities (Galgani and Nagayama 1988). Proteolytic activity, in turn, is often provided by enzymes which belong to the class of serine proteinase, i.e. by trypsin-like or chymotrypsin-like enzymes (Dittrich 1992a, b; Sakharov et al. 1994). Decapods investigated so far for trypsin mostly showed high activities of this enzyme. Moreover, trypsin from some crustaceans, like the edible crab Cancer pagurus, showed extraordinary high in vitro stability (Saborowski et al. 2004). Trypsin-like enzymes were suggested to be the most important proteolytic enzymes in the digestive tract of 
crustaceans (Dall and Moriarty 1983; García-Carreño et al. 1997; Ceccaldi 1997). However, caridean shrimps of the species Crangon crangon and Crangon allmani showed extremely variable levels of tryptic activity (Teschke and Saborowski 2005). While most of the shrimps from different coastal areas in the German Bight showed very low or none tryptic activities, about $10 \%$ of the animals expressed high or, occasionally, very high activities. Simultaneously, cysteine proteinases such as cathepsin L-like enzymes were present in the midgut glands of both species (Teschke and Saborowski 2005). No obvious relation between the appearance of tryptic enzymes, their activity levels and the diets of shrimps was observed. Therefore, the reason for this unusual pattern of trypsin expression is still unknown. However, this knowledge is important for the understanding of both the digestive physiology of $C$. crangon and for the extraordinary ecological success of this species in the coastal and Wadden areas of the North Sea. Accordingly, the aims of the present work were firstly to verify and to characterize the serine endopeptidases trypsin and chymotrypsin in the brown shrimp Crangon crangon and secondly to study the appearance of polymorphic endopeptidases in field samples from the inner German Bight.

\section{Methods}

Origin of animals

North Sea shrimps, Crangon crangon, were captured in November and December 2003 with R/V Aade by repeated short hols with a dredge at Helgoland Dünenhafen $\left(54^{\circ} 11^{\prime}\right.$ N, 0754' E). In March 2004, additional Crangon samples were taken with $\mathrm{R} / \mathrm{V}$ Uthörn from the estuaries of the rivers Weser $\left(54^{\circ} 02^{\prime} \mathrm{N}, 08^{\circ} 25^{\prime} \mathrm{E}\right)$ and Elbe $\left(53^{\circ} 49^{\prime} \mathrm{N}, 08^{\circ} 07^{\prime} \mathrm{E}\right)$, (Fig. 1). Animals were immediately sorted from the net into aquaria and shipped alive to the laboratories of the Marine Station at Helgoland. The next day, individuals were randomly selected from the aquaria. The animals were blotted dry and the fresh weight was recorded. The total length (TL) was measured under a stereo microscope and the sex was determined. The cephalothorax of the shrimps was opened dorsally and the maturation stage of

Fig. 1 The sampling sites in the inner German Bight around the island of Helgoland and in the estuaries of the rivers Weser and Elbe

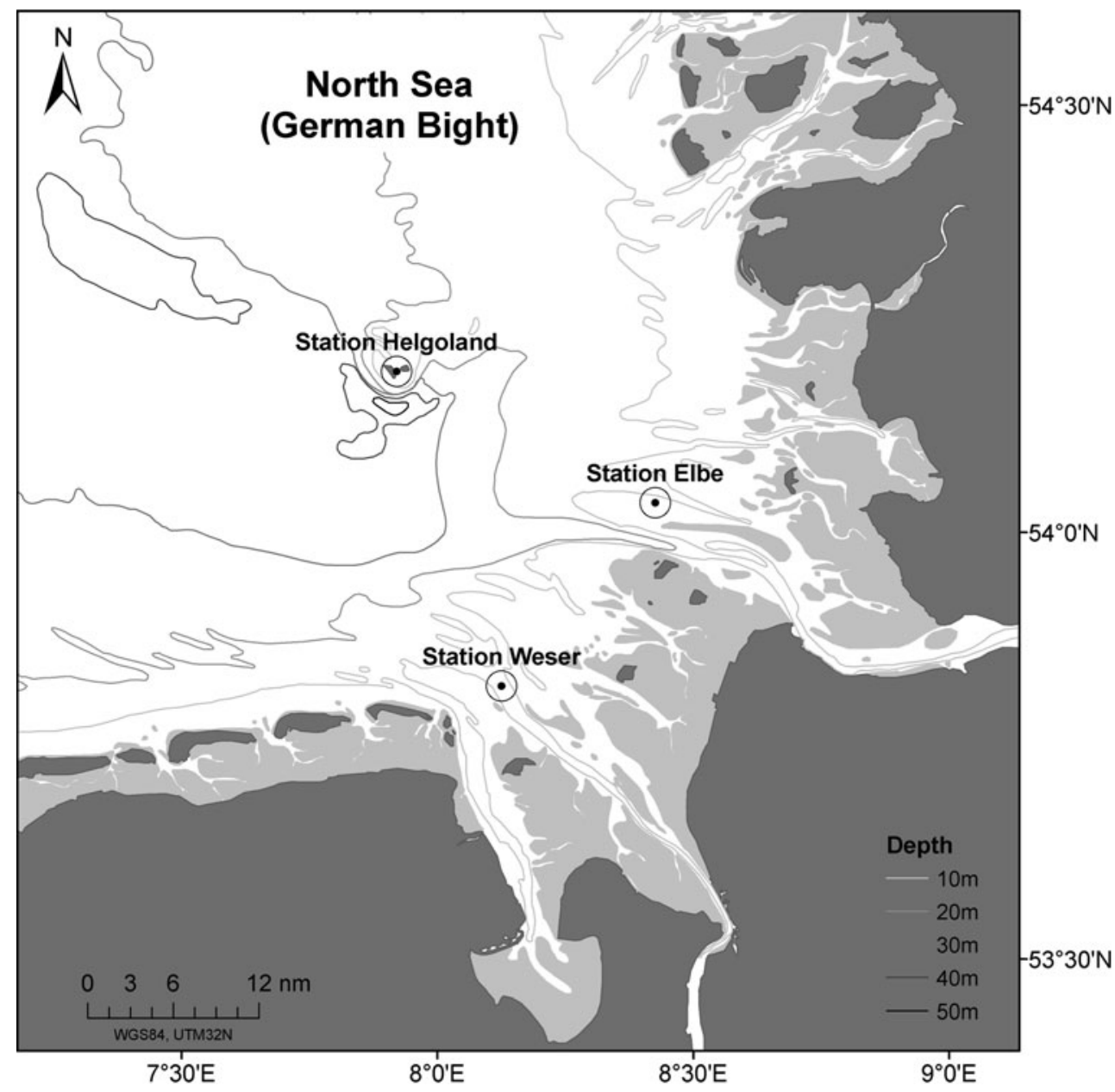


Table 1 Substrates used for enzyme assays

\begin{tabular}{lllll}
\hline Enzyme & EC-number & Substrate & Abbreviation & Source \\
\hline Trypsin (peptidase) & 3.4 .21 .4 & $N \alpha$-benzoyl-L-arginine-4-nitroanilide-hydrochloride & L-BANA & Fluka, 12915 \\
Trypsin (esterase) & 3.4 .21 .4 & $N \alpha$-tosyl-L-arginine methyl ester & TAME & Sigma, T4626 \\
Chymotrypsin & 3.4 .21 .1 & $N$-succinyl-ala-ala-pro-phe- $p$-nitroanilide & SAAPPNA & Sigma, S7388 \\
Collagenase & 3.4 .24 & $N$-(3-[-2-furyl]acryloyl)-leu-gly-pro-ala & FALGPA & Sigma, F5135 \\
Elastase & 3.4 .21 & $N$-succinyl-ala-ala-ala- $p$-nitroanilide & SAAAPNA & Sigma, 4760 \\
Leucyl-aminopeptidase & 3.4 .11 .1 & L-leucine- $p$-nitroanilide-hydrochloride & Leu-pNA & Sigma, L2158 \\
Prolyl-aminopeptidase & 3.4 .11 .5 & L-proline- $p$-nitroanilide trifluoroacetat & Pro-pNA & Sigma, P5276 \\
Alanyl-aminopeptidase & 3.4 .11 .2 & L-alanine- $p$-nitroanilide-hydrochloride & Ala-pNA & Sigma, A9325 \\
\hline
\end{tabular}

the ovaries was recorded. The midgut glands were dissected, weighed and transferred into $1.5-\mathrm{ml}$ reaction cups. One $\mathrm{ml}$ of ice-cold demineralized water (a. dem.) was added to each cup.

\section{Preparation of extracts}

The midgut glands were homogenized with an ultrasonic cell disrupter (Branson, Sonifier B15 equipped with a microtip). Three bursts of $5 \mathrm{~s}$ at $30 \%$ of maximum energy were applied while the sample was cooled on ice. Thereafter, the samples were centrifuged for $15 \mathrm{~min}$ at $15,000 \mathrm{~g}$ and $4{ }^{\circ} \mathrm{C}$. The supernatants were transferred into new reaction cups. The centrifugation step was repeated when the amount of lipids on the surface was high and lipids remained in the aqueous phase. Sub-samples of the extracts $(10 \mu \mathrm{l})$ were taken, diluted 1:20 with water and used for subsequent enzyme screening. The remaining extracts were stored at $-80{ }^{\circ} \mathrm{C}$.

\section{Enzyme and protein assays}

Screening for trypsin and chymotrypsin activity was carried out in midgut gland extracts of each animal. On each of two separate microplates $50 \mu \mathrm{l}$ of diluted extract (1:20 in a. dem.) were applied. The reaction was started subsequently by the addition of $250 \mu \mathrm{l}$ of $0.1 \mathrm{~mol}^{-1}$ Tris $\mathrm{HCl}$ (supplemented with $10 \mathrm{mmol}^{-1} \mathrm{Ca}^{2+}$ ) which contained the substrates BAPNA or SAAPPNA (Table 1). The substrates were first dissolved in dimethylsulphoxide (DMSO) and then diluted with buffer $\left(0.1 \mathrm{~mol}^{-1}\right.$ Tris $\mathrm{HCl}+$ $10 \mathrm{mmol}^{-1} \mathrm{Ca}^{2+}$ ) to a final concentration of $1 \mathrm{mmol} \mathrm{l}^{-1}$. Trypsin activity was measured at $\mathrm{pH} 8$ and chymotrypsin at $\mathrm{pH}$ 7. The microplates were incubated at room temperature. The optical density of the plates was read at $405 \mathrm{~nm}$ $\left(\mathrm{OD}_{405}\right)$ after 15,30 and $45 \mathrm{~min}$. The change in optical density was normalized to fresh weight $\left(\Delta \mathrm{OD}_{405}\right.$ $\min ^{-1} \mathrm{~g}_{\mathrm{fw}}^{-1}$ ). Samples that showed activities higher than 10
$\mathrm{OD}_{405} \min ^{-1} \mathrm{~g}_{\mathrm{fw}}^{-1}$ were used for subsequent chromatographic enzyme separation. In these samples, activities of trypsin and chymotrypsin were additionally quantified in a spectrophotometer at $410 \mathrm{~nm}$. Fifty $\mu \mathrm{l}$ of extracts and $930 \mu \mathrm{l}$ of buffer were mixed in a glass cuvette and incubated for $5 \mathrm{~min}$ at $30{ }^{\circ} \mathrm{C}$ in a temperature-controlled cuvette holder. Substrate solution $(20 \mu \mathrm{l})$ was added to start the reaction and the increase in absorbance was continuously monitored for another $3 \mathrm{~min}$. The substrate concentration in the reaction mixture amounted to $1 \mathrm{mmol} \mathrm{l}^{-1}$. The extinction coefficient for substrates that liberate nitroanilide was $10.21 \mathrm{mmol}^{-1} \mathrm{~cm}^{-1}$ (Rick $1974 \mathrm{a}$, b). Activity results obtained by each method, microplate screening or cuvette measurements, were closely correlated (trypsin: $r^{2}=0.994$; cymotrypsin: $r^{2}=0.903 ; p<0.001, n=25$ each). Esterase activity of trypsin using TAME as substrate was measured at $240 \mathrm{~nm}$ in quartz cuvettes (Geiger and Fritz 1984). Enzyme activity was normalized for protein or fresh weight. Additionally, the extracts were analysed for a set of endo- and exo-peptidases with the substrates listed in Table 1.

The protein was measured in midgut gland extracts and in separated enzymes after Bradford (1976) with a commercial protein assay (BioRad, 600-0005). Bovine serum albumin $\left(0.1 \mathrm{mg} \mathrm{ml}^{-1}\right)$ was used as protein standard. The assay was carried out in microplates.

\section{Inhibitor assays}

Extracts of those midgut glands, which showed elevated trypsin or chymotrypsin activities, were incubated with selected inhibitors (Table 2). These inhibitors either generally inhibited proteases and protease classes, or they inhibited specific enzymes. Enzyme solutions $(20 \mu \mathrm{l})$ were incubated at $25{ }^{\circ} \mathrm{C}$ with $20 \mu \mathrm{l}$ of inhibitor solutions $\left(1 \mathrm{mmol}^{-1}\right)$ and for control with the solvent of the inhibitor solution. After $60 \mathrm{~min}$ of incubation, the extracts were subjected to cuvette activity assays for trypsin and 
Table 2 List of enzyme inhibitors

\begin{tabular}{lllll}
\hline Enzyme/enzyme class & EC-number & Inhibitor & Abbreviation & Source \\
\hline Proteases & 3.4. & Phenylmethylsulfonyl fluorid & PMSF & Sigma, P7626 \\
Proteases/Serineproteases & $3.4 .(21)$ & Soybean trypsin inhibitor & SBTI & Sigma, T9128 \\
Serineproteases & 3.4 .21 & 4-(2-aminoethyl)enzenesulfonyl-fluorid hydrochloride & AEBSF & Merck, 124839 \\
Cysteineproteases & 3.4 .22 & Trans-epoxy-succinyl-L-leucylamido-(4-guanidino)-butane & E64 & Sigma, E3132 \\
Trypsin & 3.4 .21 .4 & $N$ - $p$-tosyl-L-lysin chloromethyl ketone & TLCK & Sigma, T7254 \\
Chymotrypsin & 3.4 .11 .1 & $N \alpha$ - $p$-tosyl-L-phenylalanin chloromethyl ketone & TPCK & Sigma, L4376 \\
\hline
\end{tabular}

chymotrypsin as described previously. The residual activity after inhibition was presented in relation to the uninhibited control which was set to be $100 \%$.

\section{Chromatographic separation of enzymes}

Extracts were first desalted and rebuffed over NAP-10 gelfiltration columns (Pharmacia Biotech). Subsequently, the extracts were separated by anion exchange chromatography using an FPLC-system. Extracts $(1.5 \mathrm{ml})$ were applied onto a UNO Q1 R-column (BioRad). Proteins were eluted from the column by increasing the concentration of $\mathrm{NaCl}$ from 0 to $1 \mathrm{~mol}^{-1}$ in the buffer (imidazole, $0.01 \mathrm{~mol} \mathrm{l}^{-1}$, $\mathrm{pH}$ 6.8). The flow rate was $1 \mathrm{ml} \mathrm{l}^{-1}$. The absorbance was detected at $280 \mathrm{~nm}$ (protein) with an Uvicord SII monitor. The extracts were separated into 55 fractions of $0.5 \mathrm{ml}$ each and immediately screened for enzyme activities in 96-well microplate assays as described previously. Fractions with maximum enzyme activities were pooled. In order to document the purification progress, the enzyme activities and protein concentrations were measured after each purification step.

\section{Substrate PAGE and IEF}

Proteins were separated by SDS-PAGE (12\%T, 2.8\%C) in a vertical Hoefer SE 250 electrophoresis device. Midgut gland extracts and isolated enzymes were diluted 1:2 with sample buffer which contained $4 \%$ SDS. The samples were neither heated nor treated with mercaptoethanol. The gels were loaded with 10-20 $\mu \mathrm{l}$ of samples per lane and $5 \mu \mathrm{l}$ of molecular weight markers (Low Range Markers, Sigma M 3913). Electrophoresis was performed at constant current of $15 \mathrm{~mA}$ per gel and at $2-4{ }^{\circ} \mathrm{C}$.

Bands of active endopeptidases were visualized according to García-Carreño et al. (1993). After electrophoretic separation, one of the gels was first thoroughly washed in demineralized water (a. dem.). Then, it was incubated in an ice-cooled solution of $3 \%(\mathrm{w} / \mathrm{v})$ casein (Sigma, C-5890), dissolved in $0.1 \mathrm{~mol}^{-1}$ Tris $\mathrm{HCl}, \mathrm{pH} 8$. The casein was allowed to penetrate into the gel for
$30 \mathrm{~min}$. Thereafter, the temperature was increased to about $30{ }^{\circ} \mathrm{C}$ and the gel was incubated for another $60 \mathrm{~min}$ in the casein solution. The casein solution was discarded and the gel was washed several times in a. dem. The gel was coomassie-stained over night and destained with an aqueous solution containing $40 \%$ (v/v) methanol and $7 \%(\mathrm{v} / \mathrm{v})$ glacial acetic acid. Bands with endopeptidase activity appeared pale on an otherwise blue-dyed casein containing gel. The gels were photographed (BioRad, ChemiDoc) and the relative mobility of the bands was analysed using the program QuantityOne (BioRad).

Isoelectric focussing (IEF) was carried out on commercial gels with a pH gradient from 3.5 to 9.5 (Ampholine PAGplate, Amersham Bioscience 18-1016-67). Ten $\mu$ l of the samples (crude extracts and isolated enzymes), as well as IEF-standards (BioRad, 161-0310) were applied onto the gel with the help of small pieces of filter papers $(5 \times 3 \mathrm{~mm})$. IEF was run for $1.5 \mathrm{~h}$ at $1,500 \mathrm{~V}, 50 \mathrm{~mA}$ and $30 \mathrm{~W}$ in a horizontal system (Pharmacia Biotech, Multiphor II). The protein bands were detected by silver staining (Silver staining kit—protein, Pharmacia Biotech 71-7177-00).

Temperature-activity profile and thermal stability

The thermal profile of enzyme activity was measured at temperatures between 5 and $75^{\circ} \mathrm{C}$. The incubation was performed in a temperature-controlled cuvette holder. Buffer and substrate were incubated for $5 \mathrm{~min}$ before the reaction was initiated with enzyme extract.

The thermal stabilities of trypsin and chymotrypsin were determined over a period of $5 \mathrm{~h}$. Samples were incubated at temperatures between 0 and $50{ }^{\circ} \mathrm{C}$. Thereafter, enzyme activities were measured every $30 \mathrm{~min}$ under standard conditions $\left(30^{\circ} \mathrm{C}\right)$. In each experiment, the activities of trypsin and chymotrypsin were presented in relation to the maximum average activity.

\section{Statistics}

Data sets were presented as mean and standard deviation (SD). Differences among data sets were analysed by 
ANOVA followed by a Tukey's multicomparison test. Differences are reported as statistically significant when $p<0.05$.

The effect of sex, origin (Helgoland vs. Estuaries) and six quantitative independent variables (total length, carapace length, weight, MD index, midgut gland weight and trypsin activity) on the appearance of protein bands were analysed with canonical analysis of principal coordinates (CAP: Anderson and Willis 2003, Anderson 2003). Each term in the analysis was tested using 4,999 permutations of the appropriate units. For these analyses, we used presence/ absence data and the Sorensen index. We did not consider the separate effect of Weser and Elbe estuaries due to the relatively low number of individuals collected in each of these sites compared with Helgoland. We tested for differences between Elbe and Weser but we found no significant differences (see "Results").

Patterns obtained with CAP were checked by evaluating the effect of independent variables on the protein bands that most contributed to the formation of the canonical axes. This evaluation was done with a log-linear analysis for the effect of 'Sex' and 'Origin', and Generalized Linear Model (GzLM) with binomial error structure and Logit link function.

\section{Results}

Size and sex distribution

Crangon crangon showed a distinct sexual dimorphism. The largest female was $57 \mathrm{~mm}$ long. Males were at maximum $44 \mathrm{~mm}$ and on average smaller than the females of the respective sampling site. For a better overview, size classes of $2 \mathrm{~mm}$ intervals were classified. The sex distribution within the size classes varied between sampling sites (Fig. 2a, b). The samples from the estuaries contained less immature females $(10 \%)$ than the samples from Helgoland (20-22\%). In general, there were more large animals caught around Helgoland than at the estuaries of Elbe and Weser.

\section{Enzyme activities}

The majority of the animals (80\%) showed no trypsin activity or very low activity $\left(<0.25 \mathrm{OD}_{405} \mathrm{~min}^{-1} \mathrm{~g}_{\mathrm{fw}}^{-1}\right)$. Only few animals had elevated activities of more than 0.25 $\mathrm{OD}_{405} \min ^{-1} \mathrm{~g}_{\mathrm{fw}}^{-1}$ (Fig. 3). Less than 5\% of the tested individuals expressed a trypsin activity higher than 1.0 $\mathrm{OD}_{405} \min ^{-1} \mathrm{~g}_{\mathrm{fw}}^{-1}$. The data follow a Poisson distribution of trypsin activities (occurrences of an event that happens rarely) within the entity of tested animals. The activities of chymotrypsin were much lower than those of trypsin
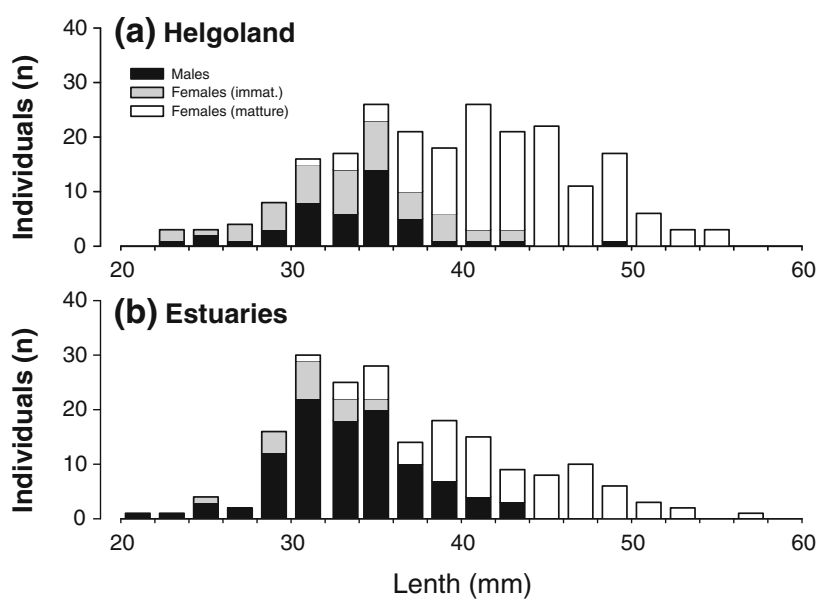

Fig. 2 Size and sex distribution of Crangon crangon from a Helgoland and from $\mathbf{b}$ the estuaries

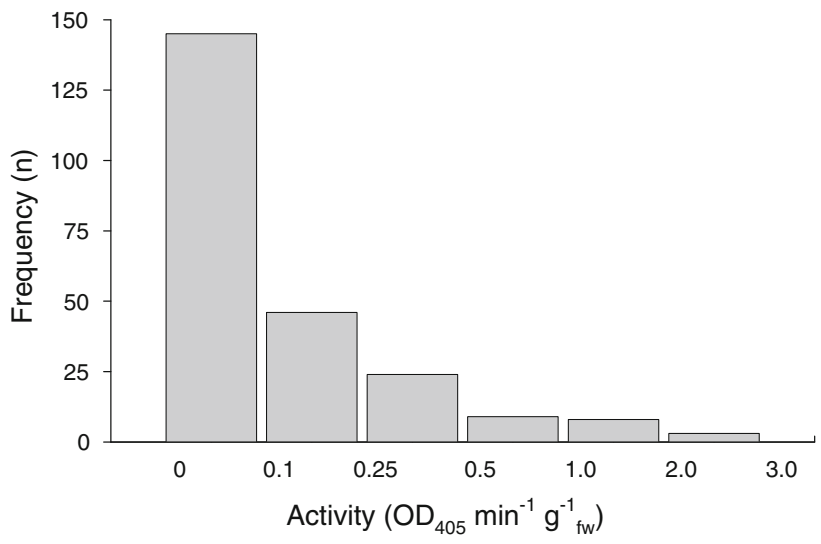

Fig. 3 Frequencies of trypsin activities in Crangon crangon from Helgoland and the estuaries $(n=235)$

reaching a maximum of only $0.3 \mathrm{OD}_{405} \mathrm{~min}^{-1} \mathrm{~g}_{\mathrm{fw}}^{-1}$ (data not shown). There was a weak correlation between trypsin and chymotrypsin activities $\left(r^{2}=0.035, p=0.01\right.$, $n=376)$.

\section{Chromatographic separation}

Midgut gland extracts were separated by anionic exchange chromatography. The elution profile showed highest trypsin activity in fractions 31 to fraction 34 (Fig. 4). Chymotrypsin was for the most part separated from trypsin. Highest chymotrypsin activities appeared in fractions 25-29 although some activity was detected in fraction 18-23 and also in fractions 30-35. Trypsin was enriched 13-fold and chymotrypsin 11-fold. Fractions with maximum activity were pooled and used for further characterization. The insert shows the electrophoretic separation and activity staining of chymotrypsin (fraction 28) and trypsin (fraction 33). 
Substrate specificity

Trypsin and chymotrypsin were incubated with different substrates but under otherwise identical conditions. Highest activity for trypsin was obtained with L-BAPA and was set to be $100 \%$ (Fig. 5a). SAAPNA and TAME were hydrolysed by Crangon trypsin to a lesser extent (45 and 19\%) and varied strongly. All other substrates were hydrolysed only marginally.

Chymotrypsin hydrolysed SAAPPNA at highest rates (Fig. 5b). Moreover, L-BAPA was hydrolysed at a lower rate $(20 \%)$ and showed high variability. A low turnover rate of prolyl- and alanyl-aminopeptidase was recorded $(<5 \%)$, while no activity was observed with the substrates FALGPA, TAME, SAAAPNA and L-pNA.

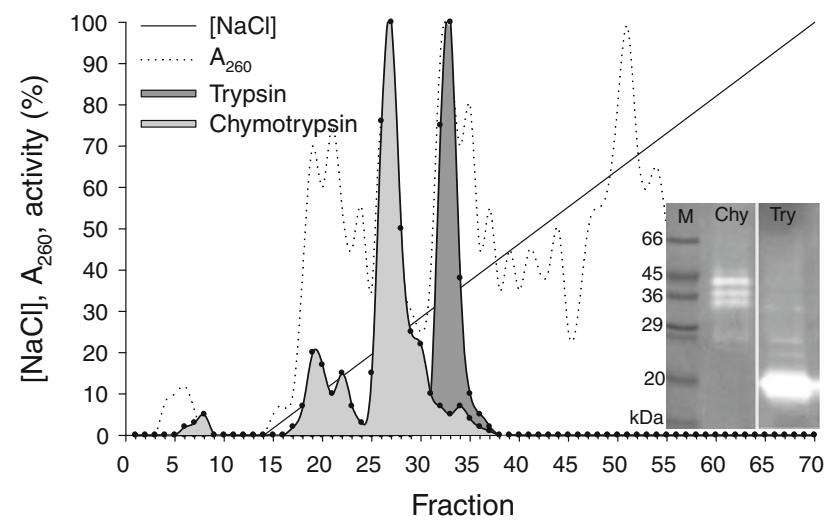

Fig. 4 Example of an elution profile of an extract from the midgut gland of Crangon crangon with high trypsin activity
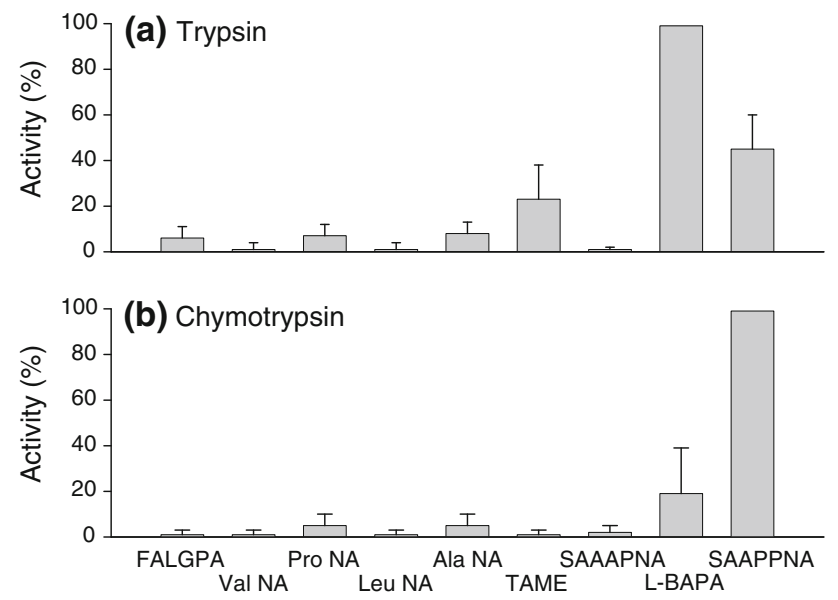

Fig. 5 Hydrolysis of different substrates (for details refer to Table 1) by $\mathbf{a}$ trypsin and $\mathbf{b}$ chymotrypsin from midgut gland extracts of Cangon crangon. The activities of the respective specific substrates L-BAPA for trypsin and SAAPPNA for chymotrypsin were set to $100 \%(n=3-5)$
Effects of inhibitors

Activities of trypsin and chymotrypsin were measured without inhibitors and set to be $100 \%$ (Fig. 6a). Trypsin activity was almost completely inhibited by SBTI, PMSF and AEBSF (1-5\% remaining activity), as well as the trypsin-specific inhibitor TLCK (8\% remaining activity). TPCK that binds to chymotrypsin also caused a significant decrease in trypsin activity (30\% remaining activity).

Chymotrypsin activity was strongest reduced by the proteinase inhibitors SBTI, PMSF and AEBSF (10\% remaining activity, Fig. 6b). Additionally, TPCK very effectively inhibited chymotrypsin activity to $<10 \%$. But also TLCK caused a $50 \%$ reduction in chymotrypsin activity.

\section{Operational parameters}

The isoelectric points $(p I)$ of $C$. crangon trypsin and chymotrypsin are similar amounting to 3.9 for trypsin and 4.0 for chymotrypsin (data not shown).

Thermal profiles: At $5{ }^{\circ} \mathrm{C}$, the tryptic activity amounted to $<10 \%$ of the maximum. With increasing incubation temperatures, the activity rose exponentially until a maximum activity appeared at $45^{\circ} \mathrm{C}$. Temperatures above $45{ }^{\circ} \mathrm{C}$ caused a rapid loss of activity. The thermal profile of chymotrypsin was similar to that of trypsin. However, maximum activity appeared at $55{ }^{\circ} \mathrm{C}$ (data not shown).

Thermal stability: When kept at temperatures lower than $40{ }^{\circ} \mathrm{C}$ or on ice, the activity of isolated trypsin remained stable for at least $5 \mathrm{~h}$. After $5 \mathrm{~h}$, a slight decrease in activity (80\%) was recorded. Incubation of trypsin at $43{ }^{\circ} \mathrm{C}$ resulted in reduced enzyme activity after just $1 \mathrm{~h}$. After $5 \mathrm{~h}$, trypsin activity was already reduced to about $50 \%$.

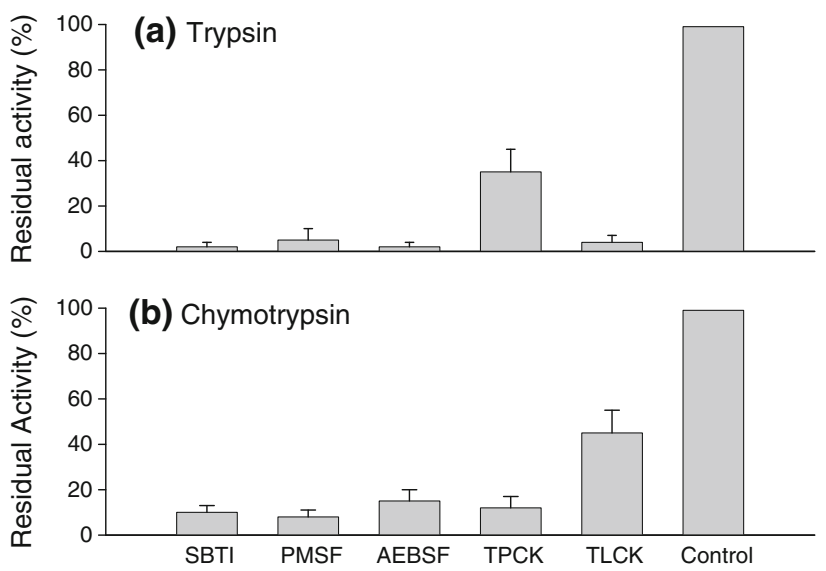

Fig. 6 Inhibition of $\mathbf{a}$ trypsin and $\mathbf{b}$ chymotrypsin activities of midgut gland extracts from Crangon crangon by different proteinase inhibitors (for details refer to Table 2). The 'control' represents untreated samples and was set to $100 \%(n=3-5)$ 
With raising temperatures, the loss of trypsin activity was more rapid, and at an incubation temperature of $50{ }^{\circ} \mathrm{C}$, it was instantly lost. Chymotrypsin also remained stable for at least $5 \mathrm{~h}$ when incubated at $<40{ }^{\circ} \mathrm{C}$. Higher temperatures caused a rapid decrease in activity (data not shown).

\section{Endopeptidase zymograms}

Zymograms of crude midgut gland extracts showed a heterogenous pattern of proteolytic enzymes between different C. crangon individuals. An example of 9 individuals is shown in Fig. 7. Single individuals differed from each others in size and number of different endopeptidases as well as in the intensity in which different endopeptidases were expressed. In total, activity bands with 30 different apparent molecular masses were detected. Of 61 analysed shrimps, which expressed trypsin activity only very few shrimps showed the same endopeptidase expression pattern. Only one group of three animals and two other groups of two animals each shared the same enzyme pattern.

\section{Inhibition of endopeptidases activity bands}

From the most frequently appearing activity bands, seven bands in the range of $20-85 \mathrm{kDa}$ were selected and their response to different inhibitors was studied. Individual C. crangon showed only few of these bands which, moreover, altered between specimens. Therefore, we extracted and combined the results and present them as a sketch (Fig. 8). Inhibition of a midgut gland homogenate with different protease inhibitors resulted in the loss of distinct bands compared with the non-inhibited homogenate which are denoted a 'Control'. The application of specific inhibitors like TLCK (binds trypsin) left more active enzymes in the homogenate than inhibitors that target a broad variety of endopeptidases. AEBSF, for instance, which binds the

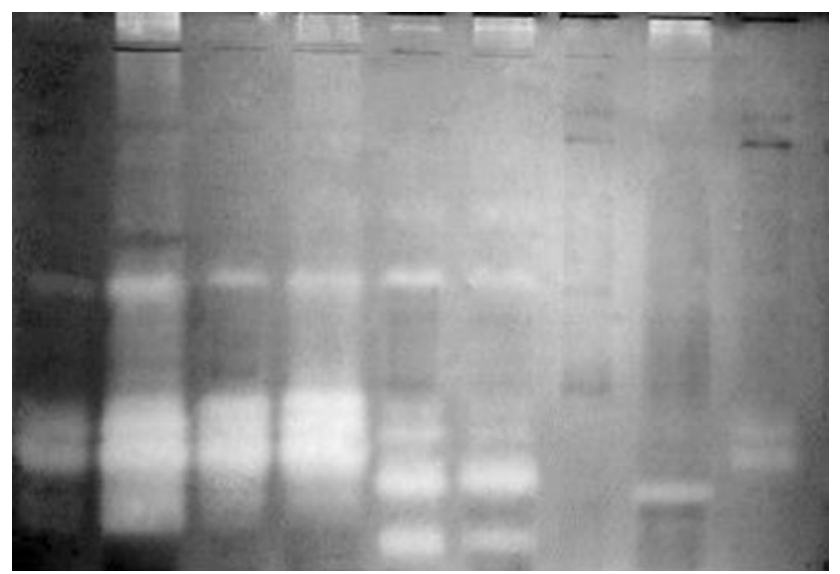

Fig. 7 Example of a native activity gel of midgut gland endopeptidases at $\mathrm{pH} 8$ from different and randomly chosen $C$. crangon

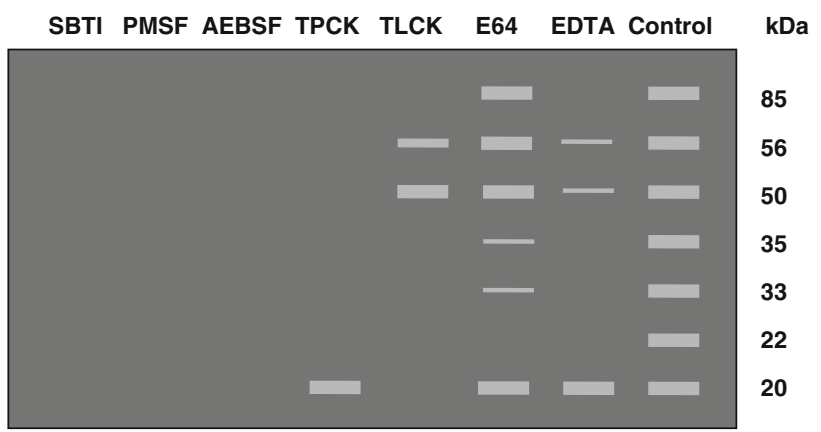

Fig. 8 Sketch showing the electrophoretic separation of the 7 most frequent proteolytic activity bands (light grey) from midgut gland extracts of $C$. crangon. The inhibition of the activity bands with specific inhibitors (see Table 2) is illustrated. The 'Control'-lane represents full activity of all 7 bands. SBTI, PMSF and AEBSF entirely inhibited all bands. TPCK, for example, inhibited all bands but not the one at $20-\mathrm{kDa}$

active serine in the catalytic centre of the enzyme, suppressed all proteolytic activity.

In most homogenates, all activity bands were inhibited by the protease inhibitors (SBTI and PMSF) and the serine protease inhibitor (AEBSF). Many bands were inhibited by TPCK as well as TLCK. Inhibitors of metallo and cysteine proteinases affected the proteolytic bands of $C$. crangon to a lesser extent.

A 20-kDa band was inhibited by the general proteinase inhibitors SBTI and PMSF as well as by AEBSF the specific serine proteinase inhibitor and the specific trypsin inhibitor TLCK. TPCK, an inhibitor specific for chymotrypsin, did not affect the 20-kDa activity band. Neither was this band inhibited by metalloproteinase- or cysteineproteinase inhibitors.

\section{Correlation analysis}

Pairwise correlation between tryptic and chymotryptic activities versus morphometric parameters (total length $=$ $\mathrm{TL}$, total weight $=\mathrm{TW}$ and midgut gland index $=\mathrm{MI}$ ) on the other side showed no strong correlation (Table 3). The correlation coefficient was highest for trypsin and chymotrypsin activity $(0.188, p=0.01)$ and second highest for trypsin activity and total length $(0.178, p=0.014)$. Linear regression also showed the best fit for trypsin and chymotrypsin $\left(r^{2}=0.035, p=0.01\right)$ and for trypsin and total length $\left(r^{2}=0.032, p=0.014\right)$.

Canonical analysis

Canonical analysis of principal coordinates (CAP) based on 25 protein bands present at least in one individual did not find any significant difference between Elbe and Weser (permutation test: $0.18, p=0.85$ ): data from these 
Table 3 Correlation analysis and linear regression between enzyme activities and somatic parameters of all individuals caught at all sampling sites. $\left(\mathrm{n}_{\mathrm{all}}=376\right)$

\begin{tabular}{llllr}
\hline & & Correlation & \multicolumn{2}{l}{ Linear regression } \\
\cline { 4 - 5 } Dependent & Independent & Coefficient & Coefficient & $r^{2}$ \\
\hline Chymotrypsin & Total length & 0.116 & 0.316 & 0.013 \\
Chymotrypsin & Total fresh mass & 0.088 & 0.341 & 0.112 \\
Chymotrypsin & Midgut gland index & 0.036 & 4.406 & 0.008 \\
Trypsin & Total length & 0.178 & 2.551 & 0.001 \\
Trypsin & Midgut gland index & 0.025 & 15.390 & 0.032 \\
Trypsin & Chymotrypsin & 0.188 & 0.967 & 0.001 \\
\hline
\end{tabular}

estuaries were pooled and compared with data from Helgoland using all 30 protein bands.

There was a significant association of protein bands with the factors sex, origin and with quantitative variables (CAP: $p<0.01$ for all tests). For either Sex or Origin, a single canonical axis was obtained by CAP: these axes are plotted together in Fig. 9. The 'leave one out allocation procedure' showed individuals were correctly allocated into groups with $75 \%$ success for sex and $73 \%$ for origin. The separation of individuals in sexes by the canonical axis can be appreciated in Fig. 9a (horizonal axis); while the separation by origin is shown in Fig. 9b (vertical axis). The bands which most contributed to the formation of the axes were of rather low molecular weight (22.6, 32.0 and 63.5 for sex; 24.3, 32.0, 35.7 and 63.5 for origin). All these bands showed a significant association only with the respective factors (Table 4). For instance, the band 24.3 was significantly associated with origin as suggested by its high canonical correlation with the axis discriminating by origin (Table 4). However, it was not significantly associated with sex, as expected from the low canonical correlation with the axis discriminating by sex. Therefore, results of log-linear and multivariate analyses were consistent with each other.

Protein bands were also significantly associated with six quantitative variables analysed $(p<0.01)$, mostly with total length and carapace length (Fig. 10). The bands that most contributed with this associations were of medium to low molecular weight: 63.5, 43.4 and 26.6 (Table 5). All of them were significantly correlated with carapace length; the band 43.4 was only marginally correlated with total length $(p<0.10)$. Thus, for most cases, results of canonical analysis of principal coordinate and generalized linear model were consistent with each other.

\section{Discussion}

North Sea shrimps, Crangon crangon, showed extraordinary patterns of the serine proteinases trypsin and

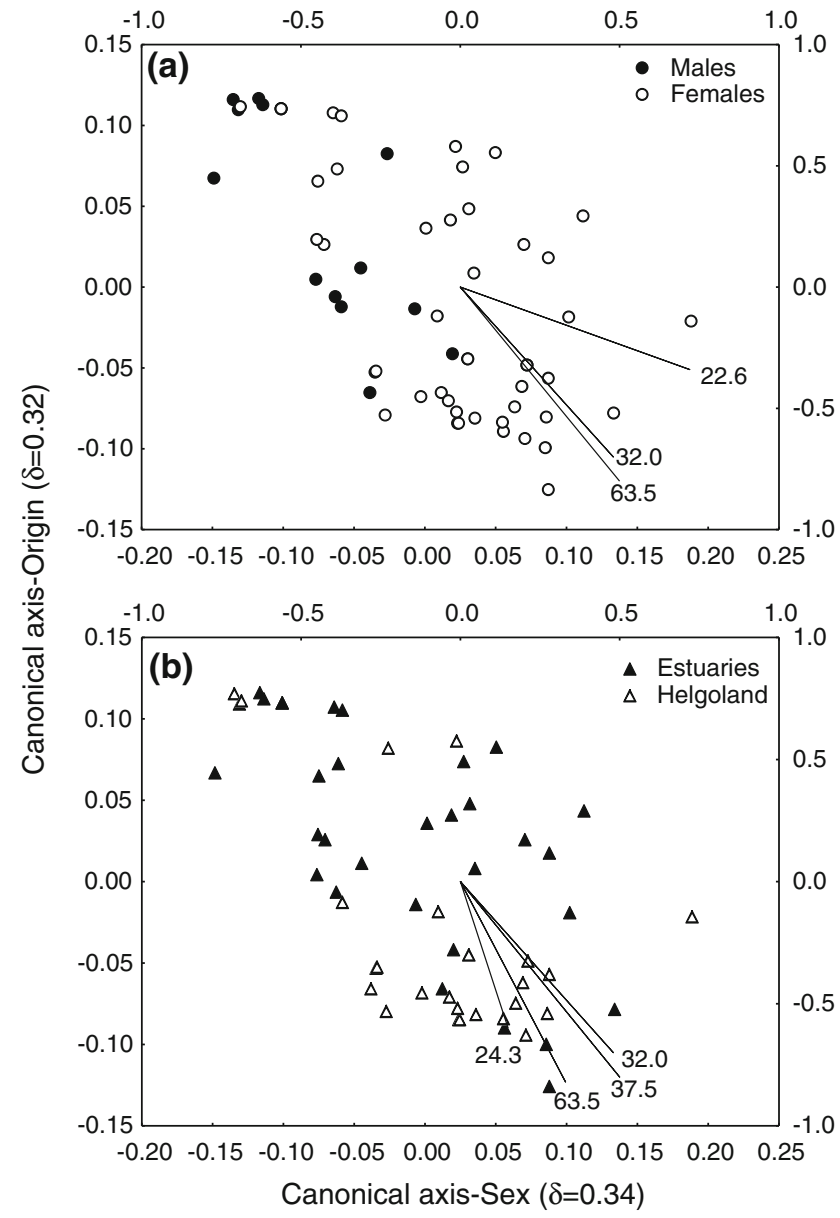

Fig. 9 Biplot of first canonical axes, obtained separately from maximization of differences between sexes and origins on the protein polymorphism. These axes are not orthogonal since they belong to separated analyses. Differences between sexes are in a along the horizontal axis; differences between origins are in the $\mathbf{b}$, along the vertical axis. Points are individuals, lines show the correlation among axes and protein weights (scales at the upper $X$ and right $Y$ axes). Only the protein weights with highest correlations with the canonical variables are shown

chymotrypsin. Significant activities of these enzymes were present only in 5-10\% of the analysed animals. Moreover, C. crangon showed a very heterogeneous pattern of 
Table 4 The proteinase bands which most contributed to the separation of sexes and origins by canonical analysis of principal coordinates

\begin{tabular}{llllll}
\hline Molecular weight & 22.6 & 24.3 & 32.0 & 35.7 & 63.5 \\
\hline Sex & & & & & \\
Canonical correlation & 0.72 & 0.15 & 0.42 & 0.33 & -0.50 \\
$\%$ (female/male) & $48.9 / 0.0$ & $35.6 / 13.3$ & $53.3 / 20.0$ & $53.3 / 40.0$ & $57.8 / 26.7$ \\
$\chi^{2}$ & 13.75 & 2.50 & 4.98 & 0.76 & 4.23 \\
$p$ & $<0.001$ & 0.11 & 0.026 & 0.38 & 0.039 \\
Origin & & & & \\
Canonical correlation & -0.34 & -0.60 & -0.70 & -0.82 & -0.80 \\
$\%$ (female/male) & $44.4 / 25.0$ & $47.2 / 4.2$ & $61.1 / 20.8$ & $69.4 / 20.8$ & $69.4 / 20.8$ \\
$\chi^{2}$ & 2.26 & 13.88 & 9.47 & 13.74 & 13.74 \\
$p$ & 0.13 & $<0.001$ & $<0.005$ & $<0.001$ & $<0.001$ \\
\hline
\end{tabular}

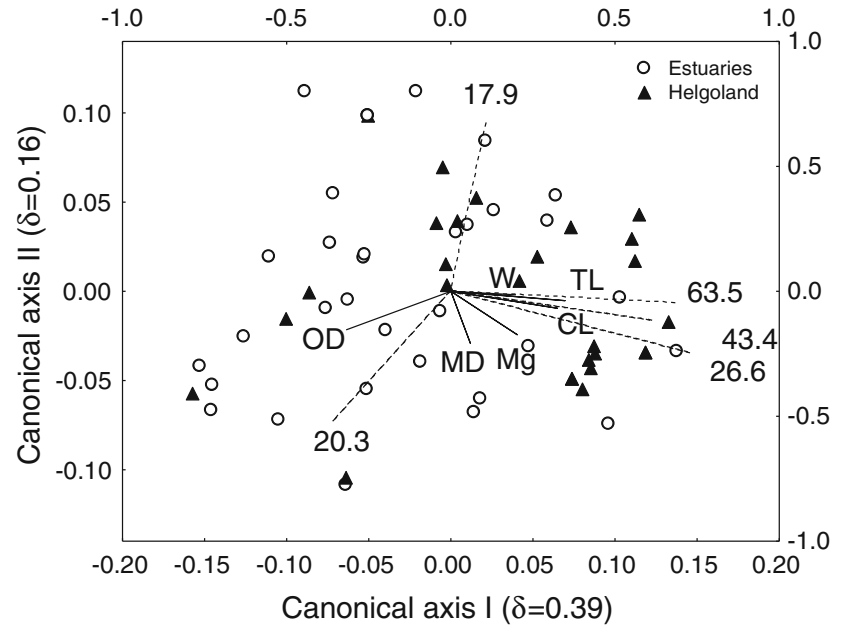

Fig. 10 Biplot of the first two canonical axes form canonical analysis of principal coordinates to investigate the effect of six quantitative variables ( $T L$ total length, $C L$ carapace length, $W$ weight, $M D$ index, $M g$ midgut gland weight, $O D$ optical density) on the protein polymorphism. Points are individuals, dashed lines are protein weights; continuous lines are quantitative variables. Only the protein weights with highest correlation with the canonical variables are shown. For each axis, the squared canonical correlation is given as $\delta^{2}$

endopeptidases. In total, 30 different activity bands were observed under native conditions. Such patterns are quite unusual for crustaceans and, to our knowledge, have not been reported previously. Of 61 analysed shrimps with high tryptic activities, only very few animals showed similar or identical expression pattern.

Expression of serine proteinases

The LC elution profiles of the specimens with high tryptic activity always showed one distinct trypsin peak and a broad chymotrypsin peak which was flanked by some peaks with lower chymotrypsin activities. These results are in accordance with data previously reported by Teschke and Saborowski (2005). Both enzymes were clearly characterized by the almost exclusive hydrolysis of the specific substrates L-BAPA, TAME and SAAPPNA, while no hydrolysis of collagenase or elastase substrates was observed. The apparent hydrolysis of SAAPPNA by trypsin and L-BAPA by chymotrypsin can be explained by incomplete chromatographic separation. The elution profiles of both enzymes overlapped slightly and, thus, traces of trypsin may have appeared in the chymotrypsin fractions and vice versa.

Trypsin and chymotrypsin from $C$. crangon showed distinct substrate specificities and a clear response to specific inhibitors. Moreover, characteristic features like the apparent molecular mass, the anionic nature of both enzymes showing low pI further support their identity.

Table 5 The proteinase bands which most contributed to the correlation with six quantitative variables in Canonical analysis of principal coordinates

\begin{tabular}{|c|c|c|c|c|c|c|}
\hline Molecular weight & \multicolumn{2}{|c|}{26.6} & \multicolumn{2}{|c|}{43.4} & \multicolumn{2}{|c|}{63.5} \\
\hline \multirow{4}{*}{$\begin{array}{l}\mathrm{CC}-1 \\
\mathrm{CC}-2\end{array}$} & \multicolumn{2}{|c|}{0.73} & \multicolumn{2}{|c|}{0.61} & \multicolumn{2}{|c|}{0.68} \\
\hline & & & & & & \\
\hline & \multicolumn{2}{|c|}{-0.25} & \multicolumn{2}{|c|}{-0.12} & \multicolumn{2}{|c|}{-0.05} \\
\hline & W & $p$ & $\mathrm{~W}$ & $p$ & $\mathrm{~W}$ & $p$ \\
\hline Total length & 4.91 & 0.026 & 3.17 & 0.075 & 4.59 & 0.032 \\
\hline Carapace length & 5.45 & 0.019 & 3.90 & 0.048 & 4.36 & 0.037 \\
\hline
\end{tabular}

Correlation with the canonical axis, and statistics of the generalized linear model (Wald test, $p$ values) 
In order to exclude the possibility that the lack of tryptic activity in the majority of specimens may have been caused by thermal degradation of the enzyme we studied the stability of trypsin and chymotrypsin at different temperatures. Both enzymes were stable on ice, at room temperature, and at $40{ }^{\circ} \mathrm{C}$ for at least $5 \mathrm{~h}$. During the routine analysis, all samples were kept on ice. Therefore, it is unlikely that temperature may have adversely affected enzyme activities during analysis.

\section{Identification of endopeptidases bands}

Animals with trypsin activities showed always a proteolytic band of apparently 20-kDa. This band corresponds with the distinct trypsin peak that was separated by liquid chromatography (Teschke and Saborowski 2005). Activity bands with other masses seemed to appear randomly but, as a tendency, their numbers were positively correlated with the trypsin activity of the sample. Most activity bands were inhibited by unspecific protease inhibitors and serine protease inhibitors. Inhibitors of metallo- and cysteineproteinases had little effect on the proteolytic bands of C. crangon. Although a significant share of proteolytic activity in $C$. crangon is contributed by cysteine proteinases (Teschke and Saborowski 2005), the low effect of cysteine inhibitors in our study is related to the analytical conditions, particularly the $\mathrm{pH}$. The optimum $\mathrm{pH}$ of cysteine proteinases is about $\mathrm{pH} 5-6$. The $\mathrm{pH}$ of the gels, however, was 8 and, thus, cysteine proteinases were not active and therefore not detectable on the zymograms.

Crangon crangon showed more than one chymotrypsin isoform by chromatographic as well as electrophoretic separation of midgut gland extracts. Elevated chymotrypsin activity was present as one major and at lest two minor peaks after anionic exchange chromatography. From the midgut gland homogenate, six bands showed chymotrypsin-like activity as demonstrated by their inhibition by TPCK.

Five of the seven proteinase bands were inhibited by TLCK. Six of the seven proteinase bands were inhibited by TPCK. Accordingly, many bands appeared which were inhibited by both TPCK and TLCK. Some of the same enzymes which were inhibited by the serine proteinase inhibitors AEBSF and the proteinase inhibitors SBTI and PMSF were also inhibited by cysteine and metallo proteinase inhibitors. These results indicate multicatalytic properties of these enzymes. A multicatalytic enzyme was described in the lobster Homarus gammarus (Clark et al. 1991). As in Crangon crangon, it was inhibited by both serine and cysteine inhibitors.

Somatic parameters and effects of nutrition

Correlation analysis indicated no significant relation between morphometric parameters and the trypsin activity.
Only the midgut gland index was weakly related with trypsin activity. The variation in enzyme activity was higher in female $C$. crangon than in male specimens. Highest variation appeared in immature females.

The feeding mode, the choice of prey and differences in food quality may alter enzyme activities. Studies on different Penaeus-species showed that trypsin activities increased when the food was poor in proteins (Le Moullac et al. 1996). In contrast, Fernández et al. (1997) and Córdova-Murueta and García-Carreño (2002) found that the activities of digestive enzymes were correlated with the amount of respective substrates in the diet. Feeding experiments with $C$. crangon, however, did not show any effect on digestive proteinase activities when algae or mussel tissue was offered as food for 14 days (Teschke and Saborowski 2005). The time of digestion may differ according to the food. In Crangon septemspinosa, some components of a dyed food entered the midgut gland already a few minutes after ingestion and reached the hindgut after $1 \mathrm{~h}$. Little later faecal pellets were released. Other components of the food, however, remained longer in the cardiac stomach, for up to $12 \mathrm{~h}$ (Wilcox and Jeffries 1974). Therefore, it cannot be excluded that enzymes which derived from ingested prey organisms may have contributed to the diverse enzyme pattern in C. crangon.

The similarity analysis indicates a relation between endopeptidase pattern and midgut gland index. There was a tendency that individuals with the same endopeptidase pattern also showed similar midgut gland indices. However, no statistically significant relation between band pattern and trypsin- and chymotrypsin activity could be established.

Large shrimp have access to a broader food spectrum. For smaller shrimps, only smaller prey is available. In this respect, the size of prey organisms is related with size of C. crangon as well (Gibson et al. 1995). Therefore, Wahle (1985) suggested to assess the feeding habits of crangonid shrimps always in relation to the life cycle. We showed in this work that this suggestion is not valid for the digestive enzymes of $C$. crangon. The activities of trypsin and chymotrypsin did not depend on the size of the studied specimens.

The ability to fill the gut is inversely related with the developmental stage of the ovaries (Plagmann 1939). During ovarian growth, feeding activity increases to meet the elevated energy demand and, thus, the gut of females often contains more food. During the time when the ovaries are fully developed the gut and the stomach are less filled because the ovaries occupy a significant amount of space within the cephalothorax (Oh et al. 2001). After spawning, the females carry the eggs ventrally attached to the pleopods until the larvae hatch. During this time, the female cannot moult. Accordingly, growth is retarded and 
consequently, the demand of energy is reduced until the larvae have hatched (Oh et al. 2001). The females usually moult after hatching and express their highest feeding activity when the new exo-skeleton is fully hardened (Plagmann 1939; Lloyd and Yonge 1947). As a result, the endopeptidase activity is highest directly after hardening of the new exoskeleton as shown in Penaeus notialis by Fernández et al. (1997).

\section{Adaptive polymorphism of endopeptidases}

It is widely accepted that heterogeneous and variable environments demand a high degree of physiological flexibility from the organisms living there. And, in turn, organisms living in a variable habitat are expected to show high abilities for adaptation (e.g. Wilcox and Jeffries 1974; Nelson and Hedgecock 1980; Abdullah and Shukor 1993). Christensen et al. (1978) saw in the heterogeneous niche of the oligochaete Lumbricus lineatus the reason for the observed protein polymorphism in this species. The unspecific feeding mode of Crangon septemspinose was interpreted by Wilcox and Jeffries (1974) as an adaptation to changing feeding conditions in an estuarine environment. C. crangon feeds omnivorously as documented from stomach analysis by Plagmann (1939) and Pihl and Rosenberg (1984). The stomach content of different shrimp individuals roughly reflected the composition of smaller benthic individuals at the sampling site. It was dominated by animals while microalgae and parts of macroalgae played a minor role (Plagmann 1939; Pihl and Rosenberg 1984). Accordingly, also the unspecific feeding habits of C. crangon can be seen as an adaptation to a variable environment which may be supported by the heterogeneity of digestive serine-endopeptidase due to the variability of food.

Nelson and Hedgecock (1980) studied in 51 species of decapod crustaceans the relation between their ecological niches and the heterozygosity of enzyme coding genes. Species with a broad food spectrum showed a higher degree of heterozygote than feeding specialists. Among the specialists, carnivorous species were more often heterozygote than herbivorous species. The climatic zone had an effect as well. Heterozygosity in crustaceans from the temperate sublittoral zones was double as high as in crustaceans from tropical sublittoral.

Most factors which, according to Nelson and Hedgecock (1980), may trigger heterozygosity do also apply for C. crangon. The animals show a broad feeding spectrum acting as predators unselectively feeding omnivorously or carnivorously (del Norte-Campos and Temming 1994; Gibson et al. 1995). The stomach contents of $C$. crangon reflect the relative abundance of potential prey organisms in the respective habitat of the Crangon specimens
(Plagmann 1939; Pihl and Rosenberg 1984; Ansell et al. 1999; Oh et al. 2001). All individuals studied here came from the sublittoral zone of the southern North Sea. The heterogeneous pattern of endopeptidases in C. crangon may suggest heterozygosity of genes coding for serine endopetidases.

Nelson and Hedgecock (1980) formed for their observations of heterozygosity the term 'adaptive polymorphism' and raised the hypothesis that it represents a suitable tool for studying evolutionary processes in variable habitats. Kimura and Ohta (1971) as well described protein polymorphism as a phase of molecular evolution. It represents the first step in the long lasting establishment of mutations within populations. The present trends in the North Sea support the suggestion that opportunistic species will dominate more in the future (Rachor and Schröder 2003). C. crangon is an opportunistic predator. If polymorphic expression of digestive enzymes is an adaptation to variable environmental conditions, then the observed endopeptidase polymorphism of $C$. crangon may reflect the acute process of adaptation of an organism to a changing environment.

Acknowledgments We gratefully acknowledge the excellent support of the crews of R/V Aade and R/V Uthörn. Dr. Jennifer Dannheim created the ArgGis 9-map of the German Bight.

\section{References}

Abdullah R, Shukor NA (1993) Isozyme variation between two closely related species Crangon crangon (L.) and Crangon allmanni Kinahan (Decapoda, Caridea). Crustaceana 64:114-121

Anderson M (2003) CAP: a FORTRAN computer program for canonical analysis of principal coordinates. Department of Statistics, University of Aukland

Anderson M, Willis T (2003) Canonical Analysis of Principal Coordinates: a useful method of constrained ordination for ecology. Ecology 84:511-525

Ansell A, Comely C, Robb L (1999) Distribution, movements and diet of macrocrustations on a Scottish sandy beach with particular reference to predation on juvenile fishes. Mar Ecol Prog Ser 176:115-130

Bradford M (1976) A rapid and sensitive method for the quantitation of microgram quantities of protein utilizing the principle of protein-dye binding. Anal Biochem 72:248-254

Ceccaldi HJ (1997) Anatomy and physiology of the digestive system. Advances in World Aquaculture. In: D'Abramo LR, Conklin DE, Akiyama DM (eds) Crustacean nutrition, vol 6. World Aquaculture Society, Baton Rouge, LA, pp 261-291

Christensen B, Jelnes J, Berg U (1978) Long-term isozyme variation in parthenogenetic polyploid forms of Lumbricillus lineatus (Enchytraeidae, Oligochaeta) in recently established environments. Hereditas 88:65-73

Clark J, Ilgen TL, Haire MF, Mykles DL (1991) Differential effects of oleic acid, sodium dodecyl sulfate, and protease inhibitors on the endopeptidase activities of the lobster multicatalytic proteinase. Comp Biochem Physiol 99B:413-417 
Córdova-Murueta JH, García-Carreño FL (2002) Nutritive value of squid and hydrolized protein supplement in shrimp feed. Aquaculture 210:371-384

Dall W, Moriarty DJW (1983) Functional aspects of nutrition and digestion. In: Mantel LE (ed) The biology of crustacea, vol 5. Internal anatomy and physiological regulation. Academic Press, New York, pp 215-261

del Norte-Campos AGC, Temming A (1994) Daily activity, feeding and rations in gobies and brown shrimp in the northern Wadden Sea. Mar Ecol Prog Ser 115:41-53

Dittrich B (1992a) Comparative studies on the thermal properties of a trypsin-like protease in two hermit crabs. Helgol Meeresunters 46:45-52

Dittrich B (1992b) Life under extreme conditions: aspects of evolutionary adaptation to temperature in crustacean proteases. Polar Biol 12:269-274

Fernández I, Oliva M, Carrillo O, Van Wormhoudt A (1997) Digestive enzyme activities of Penaeus notialis during reproduction and moulting cycle. Comp Biochem Physiol 118A:1267-1271

Galgani F, Nagayama F (1988) Digestive proteolysis and digestive proteinases in deep sea crabs Geryon affinis and Chionecetes japonicus. Bull Jap Soc Sci Fish 54:983-987

García-Carreño FL, Dimes LE, Haard NF (1993) Substrate-gel electrophoresis for composition and molecular weight of proteinases or proteinaceous proteinase inhibitors. Anal Biochem 214:65-69

García-Carreño FL, Navarrete del Toro A, Ezquerra M (1997) Digestive shrimp proteases for evaluation of protein digestibility in vitro. I: Effect of protease inhibitors in protein ingredients. J Mar Biotechnol 5:36-40

Geiger R, Fritz H (1984) Trypsin. In: Bergmeyer HU (ed) Methods of enzymatic analysis, vol 5. Verlag Chemie, Weinheim, pp 119-123

Gibson R, Yin M, Robb L (1995) The behavioural basis of predatorprey size relationships between shrimp (Crangon crangon) and juvenile plaice (Pleuronectes platessa). J Mar Biol Assoc UK 75:337-349

Kimura M, Ohta T (1971) Protein polymorphism as a phase of molecular evolution. Nature 229:467-469

Le Moullac G, Klein B, Sellos D, Van Wormhoudt A (1996) Adaptation of trypsin, chymotrypsin and $\alpha$-amylase to casein level and protein source in Penaeus vannamei (Crustacea Decapoda). J Exp Mar Biol Ecol 208:107-125
Lloyd AJ, Yonge CM (1947) The biology of Crangon vulgaris L. in the bristol channel and severn estuary. J Mar Biol Assoc UK 26:626-661

Nelson K, Hedgecock D (1980) Enzyme polymorphism and adaptive strategy in the decapod crustacea. Am Nat 116:238-280

Oh C-W, Hartnoll RG, Nash RDM (2001) Feeding ecology of the common shrimp Crangon crangon in Port Erin Bay, Isle of Man, Irish Sea. Mar Ecol Prog Ser 214:211-223

Pihl L, Rosenberg R (1984) Food selection and consumption of the shrimp Crangon crangon in some shallow marine areas in western Sweden. Mar Ecol Prog Ser 15:159-168

Plagmann J (1939) Ernährungsbiologie der Garnele (Crangon vulgaris Fabr.). Helgol wiss Meeresunters 2:113-162

Rachor E, Schröder A (2003) Auswirkungen auf das Makrozoobenthos - Nutznießer und Geschädigte der Eutrophierung. In: Lozán JL, Rachor E, Reise K, Sündermann J, von Westernhagen H (eds) Warnsignale aus Nordsee und Wattenmeer. Eine aktuelle Umweltbilanz. Verlag Wissenschaftliche Auswertungen, Hamburg, pp 201-203

Rick W (1974a) Chymotrypsin. In: Bergmeyer HU (ed) Methoden der enzymatischen Analyse. Verlag Chemie $\mathrm{GmbH}$, Weinheim, pp 1045-1051

Rick W (1974b) Trypsin. In: Bergmeyer HU (ed) Methoden der enzymatischen Analyse. Verlag Chemie GmbH, Weinheim, pp 1052-1063

Saborowski R, Sahling G, Navarrete del Toro MA, Walter I, GarcíaCarreño FL (2004) Stability and effects of organic solvents on endopeptidases from the gastric fluid of the marine crab Cancer pagurus. J Mol Catal B Enzym 30:109-118

Sakharov IYu, Litvin FE, Mitkevitch OV, Samokhin GP, Bespalova ZD (1994) Substrate specificity of collagenolytic proteases from the king crab Paralithodes camtschatica. Comp Biochem Physiol 107B:411-417

Teschke M, Saborowski R (2005) Cysteine proteinases substitute for serine proteinases in the midgut glands of Crangon crangon and Crangon allmani (Decapoda: Caridea). J Exp Mar Biol Ecol 316:213-229

Wahle RA (1985) The feeding ecology of Crangon franciscorum and Crangon nigricauda in San Francisco Bay, California. J Crust Biol 5:311-326

Wilcox JR, Jeffries HP (1974) Feeding habitats of the sand shrimp Crangon septemspinosa. Biol Bull 146:424-434 